\title{
Maternal sleep position: what do we know where do we go?
}

\author{
Louise M. O'Brien ${ }^{1 *}$, Jane Warland ${ }^{2}$ \\ From Stillbirth Summit 2014 \\ Medina, MN, USA. 19-21 June 2014
}

Good sleep is an essential component to health and wellbeing. It consumes one third of human existence; unhealthy sleep can severely impair the other two-thirds. An increasing amount of data now shows that poor sleep - such as sleep disordered breathing, poor sleep quality, and insomnia - has a negative impact on pregnancy outcomes [1-5]. Indeed, over half of the most important risk factors for stillbirth, such as maternal hypertension, gestational diabetes, and fetal growth restriction, have been shown to be associated with maternal sleep disruption [1,2,6-9]. Findings from recent studies have also suggested that maternal sleep position may be a risk factor for stillbirth $[10,11]$. It has long been recognized that posture in late pregnancy can have a profound effect on maternal hemodynamics. Studies in awake pregnant women have demonstrated reduced ejection fraction and cardiac output in the supine position compared to the left lateral position [12] that may reduce utero-placental blood flow to the fetus since the gravid uterus compresses the inferior vena cava. Failure to prevent this compression can lead to maternal supine hypotensive syndrome [13] and to an adverse effect on umbilical artery blood flow and gas exchange between mother and fetus, with consequent fetal heart rate decelerations [14] and fetal growth restriction [15].

For over 60 years it has been standard of care to place laboring pregnant women in the left lateral tilt position to displace the uterus from the inferior vena cava and improve maternal hemodynamics. Despite this knowledge, little attention has been paid to maternal sleep position during pregnancy even though we spend about one third of our life asleep. Given the known effects of inferior vena cava compression it is very possible that

\footnotetext{
* Correspondence: louiseo@med.umich.edu

${ }^{1}$ Sleep Disorders Center, Department of Neurology and the Department of Obstetrics \& Gynecology, University of Michigan, Ann Arbor, Michigan, USA Full list of author information is available at the end of the article
}

supine sleep could be a risk for stillbirth. Recent studies in Auckland, New Zealand [10], and Ghana, Africa [11] have both shown that supine sleep is independently associated with stillbirth; indeed Owusu et al [11] found that the effect of supine sleep on stillbirth was mediated via low birth weight. Both of the latter studies suggested that if supine sleep plays a causal role in stillbirth, altering the sleep position of pregnant women may reduce stillbirth by approximately $25 \%$. Of note, we have recently demonstrated that the majority of pregnant women (about $80 \%$ ) spend some time sleeping supine, with the median time being approximately one quarter of the night [16].Supine sleep may therefore represent a maternal stressor in the unexplained late stillbirth triple risk model [17]. Thus, if supine sleep plays a role in stillbirth, the majority of pregnant women would benefit from education and potential intervention. Several potential methods to reduce supine sleep include the use of mattress wedges or pillows [18] or other interventions such as the 'tennis ball' technique [19] or even novel devices that could alert a pregnant women to change position. However, before intervention studies are launched, it is pertinent that the findings regarding sleep position are repeated and confirmed in other studies; several such studies are currently underway including small studies monitoring the fetus during maternal sleep (O'Brien and Warland, personal communication) and large studies such as the MiNESS study in the UK [20] that will either support or refute the sleep position hypothesis.

\footnotetext{
Authors' details

${ }^{1}$ Sleep Disorders Center, Department of Neurology and the Department of Obstetrics \& Gynecology, University of Michigan, Ann Arbor, Michigan, USA. ${ }^{2}$ School of Nursing and Midwifery, University of South Australia, Adelaide South Australia, Australia.
}

Published: 15 April 2015 


\section{References}

1. O'Brien LM, Bullough AS, Owusu JT, Tremblay KA, Brincat CA, Kalbfleisch JD, Chervin RD: Pregnancy-Onset Habitual Snoring, Gestational Hypertension, and Pre-eclampsia: Prospective Cohort Study. Am J Obstet Gynecol 2012, 207(6):487, e1-9.

2. O'Brien L, Bullough AS, Owusu JT, Tremblay KA, Brincat CA, Chames MC, Kalbfleisch JD, Chervin RD: Habitual Snoring During Pregnancy and Delivery Outcomes: Prospective Cohort Study. Sleep 2013, 36(11):1625-32.

3. Okun ML, Luther JF, Wisniewski SR, Sit D, Prairie BA, Wisner KL: Disturbed sleep, a novel risk factor for preterm birth? J Womens Health (Larchmt) 2012, 21(1):54-60.

4. Chang JJ, Pien GW, Duntley SP, Macones GA: Sleep deprivation during pregnancy and maternal and fetal outcomes: is there a relationship? Sleep Med Rev 2010, 14(2):107-14.

5. Pien GW, Schwab RJ: Sleep disorders during pregnancy. Sleep 2004, 27(7):1405-17.

6. Bourjeily G, Raker CA, Chalhoub M, Miller MA: Pregnancy and fetal outcomes of symptoms of sleep-disordered breathing. Eur Respir J 2010 36(4):849-55.

7. Qiu C, Enquobahrie D, Frederick 10, Abetew D, Williams MA: Glucose intolerance and gestational diabetes risk in relation to sleep duration and snoring during pregnancy: a pilot study. BMC Womens Health 2010, 10:17.

8. Williams MA, Miller RS, Qiu C, Cripe SM, Gelaye B, Enquobahrie D: Associations of early pregnancy sleep duration with trimester-specific blood pressures and hypertensive disorders in pregnancy. Sleep 2010, 33(10):1363-71.

9. Fung AM, Wilson DL, Lappas M, Howard M, Barnes M, O'Donoghue F, Tong S, Esdale H, Fleming G, Walker SP: Effects of maternal obstructive sleep apnoea on fetal growth: a prospective cohort study. PLOS One 2013, 8(7):e68057

10. Stacey T, Thompson JM, Mitchell EA, Ekeroma AJ, Zuccollo JM, McCowan LM: Association between maternal sleep practices and risk of late stillbirth: a case-control study. BMJ 2011, 342:d3403.

11. Owusu JT, Anderson FJ, Coleman J, Oppong S, Seffah JD, Aikins A, O'Brien LM: Association of maternal sleep practices with pre-eclampsia, low birth weight, and stillbirth among Ghanaian women. International journal of gynaecology and obstetrics: the official organ of the International Federation of Gynaecology and Obstetrics 2013, 121(3):261-5.

12. Rossi A, Cornette J, Johnson MR, Karamermer $Y$, Springeling T, Opic $P$, Moelker A, Krestin GP, Steegers E, Roos-Hesselink J, van Geuns RJ: Quantitative cardiovascular magnetic resonance in pregnant women: cross-sectional analysis of physiological parameters throughout pregnancy and the impact of the supine position. J Cardiovasc Magn Reson 2011, 13:31.

13. Holmes F: The supine hypotensive syndrome. Its importance to the anaesthetist. Anaesthesia 1960, 15:298-306.

14. Abitbol MM: Supine position in labor and associated fetal heart rate changes. Obstetrics and gynecology 1985, 65(4):481-6.

15. Papageorghiou AT, Yu CK, Nicolaides KH: The role of uterine artery Doppler in predicting adverse pregnancy outcome. Best Pract Res Clin Obstet Gynaecol 2004, 18(3):383-96.

16. O'Brien LM, Warland J: Typical sleep positions in pregnant women. Early Hum Dev 2014, 90(6):315-7.

17. Warland J, Mitchell EA: A triple risk model for unexplained late stillbirth. BMC Pregnancy Childbirth 2014, 14:142.

18. Thomas IL, Nicklin J, Pollock H, Faulkner K: Evaluation of a maternity cushion (Ozzlo pillow) for backache and insomnia in late pregnancy. The Australian \& New Zealand journal of obstetrics \& gynaecology 1989 29(2):133-8.

19. Skinner MA, Kingshott RN, Filsell S, Taylor DR: Efficacy of the 'tennis ball technique' versus nCPAP in the management of position-dependent obstructive sleep apnoea syndrome. Respirology 2008, 13(5):708-15.

20. Platts J, Mitchell EA, Stacey T, Martin BL, Roberts D, McCowan L, Heazell AE: The Midland and North of England Stillbirth Study (MiNESS). BMC Pregnancy Childbirth 2014, 14:171.

doi:10.1186/1471-2393-15-S1-A4

Cite this article as: $O^{\prime} B r i e n$ and Warland: Maternal sleep position: what do we know where do we go? BMC Pregnancy and Childbirth 2015 15(Suppl 1):A4.

\section{Submit your next manuscript to BioMed Central and take full advantage of:}

- Convenient online submission

- Thorough peer review

- No space constraints or color figure charges

- Immediate publication on acceptance

- Inclusion in PubMed, CAS, Scopus and Google Scholar

- Research which is freely available for redistribution
Biomed Central 